Article

\title{
Climatic Changes, Water Systems, and Adaptation Challenges in Shawi Communities in the Peruvian Amazon
}

\author{
Paola A. Torres-Slimming ${ }^{1, *(1)}$, Carlee J. Wright ${ }^{2}$, Guillermo Lancha ${ }^{3}$, Cesar P. Carcamo ${ }^{4,5}$, \\ Patricia J. Garcia ${ }^{4,5}$, James D. Ford ${ }^{4,6}$, IHACC Research Team ${ }^{4,+}$ and Sherilee L. Harper 2,4 (D) \\ 1 Graduate School, Universidad Peruana Cayetano Heredia, Lima 31, Peru \\ 2 School of Public Health, University of Alberta, Edmonton, AB T6G 2R3, Canada; \\ cwright1@ualberta.ca (C.J.W.); sherilee.harper@ualberta.ca (S.L.H.) \\ 3 Puesto de Salud Nuevo Tocache, Red de Salud Lamas, San Martin 22151, Peru; nao_2485@hotmail.com \\ 4 Indigenous Health Adaptation to Climate Change Research Team, University of Alberta, Edmonton, \\ AB T6G 2R3, Canada; cesar.carcamo@upch.pe (C.P.C.); patricia.garcia@upch.pe (P.J.G.); \\ J.Ford2@leeds.ac.uk (J.D.F.); Ihacc@ualberta.ca (IHACCR.T.) \\ 5 School of Public Health and Administration, Universidad Peruana Cayetano Heredia, Lima 31, Peru \\ 6 Priestley International Centre for Climate, University of Leeds, Leeds LS2 9JT, UK \\ * Correspondence: paola.torres.s@upch.pe \\ + Indigenous Health Adaptation to Climate Change Research Team (IHACC Research Team): \\ Lea Berrang-Ford; Victoria Edge; Shuaib Lwasa; Didacus Bambaiha Namanya.
}

Received: 1 March 2020; Accepted: 11 April 2020; Published: 22 April 2020

\begin{abstract}
Climate change impacts on water systems have consequences for Indigenous communities. We documented climatic changes on water systems observed by Indigenous Shawi and resultant impacts on health and livelihoods, and explored adaptation options and challenges in partnership with two Indigenous Shawi communities in the Peruvian Amazon. Qualitative data were collected via PhotoVoice, interviews, focus group discussions, and transect walks, and analyzed using a constant comparative method and thematic analysis. Quantitative data were collected via a household survey and analyzed descriptively. Households observed seasonal weather changes over time $(\mathrm{n}=50$; $78 \%)$, which had already impacted their family and community $(\mathrm{n}=43 ; 86 \%)$, such as more intense rainfall resulting in flooding $(\mathrm{n}=29 ; 58 \%)$. Interviewees also described deforestation impacts on the nearby river, which were exacerbated by climate-related changes, including increased water temperatures (warmer weather, exacerbated by fewer trees for shading) and increased erosion and turbidity (increased rainfall, exacerbated by riverbank instability due to deforestation). No households reported community-level response plans for extreme weather events, and most did not expect government assistance when such events occurred. This study documents how Indigenous peoples are experiencing climatic impacts on water systems, and highlights how non-climatic drivers, such as deforestation, exacerbate climate change impacts on water systems and community livelihoods in the Peruvian Amazon.
\end{abstract}

Keywords: climate change; weather changes; water systems; Indigenous health; Indigenous livelihoods; Peru; Shawi

\section{Introduction}

Rapid environmental changes are occurring around the globe, driven by human activities and climate change [1-3]. Climate change impacts, including sea level rise, changes in precipitation, and increased extreme weather events [4-6] have important implications for human health and 
livelihoods. For example, climate change can directly impact human health and livelihoods via increased temperatures and heatwaves, increased heat-related morbidity and mortality, disruptions to labor activities, and increased violence and unrest [7-10]. Some of the most substantial, widespread, and severe climate change impacts, however, will affect society via indirect impacts. For instance, climate change is intensifying hydrological systems, resulting in negative impacts on water security- "the reliable availability of an acceptable quantity and quality of water for health, livelihoods and production" [11]—for millions of people around the world [1,11-14].

Projections indicate that the Amazon will experience an increase of $4{ }^{\circ} \mathrm{C}$ in annual mean surface temperature by 2070 [15-18]. Changes in rainfall are projected to vary by region in the Amazon: the eastern Amazon is projected to become much drier $[15,19]$ and the western Amazon is projected to become substantially wetter $[18,20]$. Furthermore, projections indicate that the Amazon will also be subject to more frequent and more severe high impact weather events as climate change progresses [19,21-23]. These projected changes will influence the quantity and quality of surface water, including river water used for drinking, bathing, washing, and/or food preparation [24-26]. These changes may impact livelihoods by decreasing water security [27-29] while simultaneously increasing demands on water infrastructure. Pathogens associated with water-related diseases are also affected by climate change; for example, at warmer temperatures microorganisms that cause malaria, dengue, and gastrointestinal illness can survive and multiply in higher numbers [27,30-32].

Climate change impacts on water systems in the Peruvian Amazon are particularly challenging for water security. Since 2003, an unprecedented intensification of hydrological patterns has been documented in Peru, including extreme weather events that did not align with El Niño-La Niña cycles [33]. These changes have led to a very high risk of flooding, which has already resulted in damages in the region $[34,35]$. For example, climate projections indicate that annual discharge in the Requena watershed (Ucayali basin) will increase by $20 \%-100 \%$ by the end of the century [36]. Furthermore, warmer temperatures are increasing evapotranspiration, decreasing soil moisture, and resulting in heavy rainfall not penetrating soil due to run-off $[6,37]$. These changes have already resulted in severe flooding events and challenges to water security.

In many cases, particularly in low and middle income countries including Peru, climate change impacts on water security are complicated by the high proportion of people living in extreme poverty, as well as the high numbers of people living in peri-urban areas, rural areas, and immigration settings [38-41]. More than 3,300,000 Indigenous people live in the Peruvian Amazon [42] and are considered to be among the groups most vulnerable to climate change [43,44]. The health and wellbeing of Indigenous peoples in the Amazon is often directly related to the quantity and quality of nearby surface water sources, both of which are projected to be negatively impacted as climate change progresses [45-47]. While vulnerable to climate change impacts on water security, Indigenous peoples demonstrate resilience when self-determined climate solutions are supported and promoted [45]. Indigenous knowledge systems are crucial for effective climate change responses [48,49], as they support understanding and documentation of climate change impacts as well as the development of locally-appropriate and culturally relevant climate change adaptation strategies [50]. Indeed, Indigenous knowledge is often more detailed and fine grained, and can provide more reliable observations than instrumental datasets, providing more nuanced understandings of climatic and non-climatic observations of change. Consequently, discourse surrounding meaningful engagement with Indigenous knowledge in international climate change assessments and policy has been gaining traction in recent years [48,49]. For example, organizations such as the Intergovernmental Panel on Climate Change (IPCC), the United Nations Educational, Scientific and Cultural Organization (UNESCO), and the United Nations Framework Convention on Climate Change (UNFCCC) increasingly recognize the importance of Indigenous knowledge in understanding and responding to climate change [48,49].

Though studies have examined how climate change impacts water systems [51,52], or examined how water systems impact health and livelihoods [53,54], few studies have explored where these areas of 
climate-water-livelihoods intersect [14], particularly as observed by Indigenous peoples. Even fewer studies have explored the nexus of climate-water-livelihoods in the Peruvian Amazon [55,56]. To address this gap, the goal of this study was to characterize the impacts of climate changes on water security observed by two Shawi Indigenous communities in the Peruvian Amazon. Specifically, the objectives of this study were to (1) document climatic and weather change impacts on water systems observed by Shawi; (2) characterize impacts on Shawi livelihoods; and (3) explore adaptation options and challenges.

\section{Materials and Methods}

\subsection{Community Profile: Loreto Region, Peruvian Amazon}

This study took place in the Loreto Region, which is a one-hour flight from the capital city of Lima in Peru. Loreto is located in the Amazon Rainforest, and the local population is widely dispersed across the Region. Numerous rivers cross this territory, most of which are navigable by boat. The territory has wide river floodplains as well as many ponds and oxbow lakes, locally known as cochas and tipishcas. The climate is warm and humid, with a rainy season between November and April, and a dry season between May and October. The region receives, on average, $1800 \mathrm{~mm}$ of precipitation per year, with rainfall varying widely between the rainy and dry seasons. Annual temperatures range from 21 to $32{ }^{\circ} \mathrm{C}$, with a minimum relative humidity of $74.5 \%$ and a maximum relative humidity of $81.5 \%$ [57].

Shawi are one of 65 Indigenous Peoples recognized in Peru, and they comprise one of the 13 linguistic families in the country (Shawi or Chayahuita). There are approximately 25,000 Shawi living throughout the Peruvian Amazon. In the Region of Loreto, most Shawi communities are located along the basins of the Paranapura, Yanayacu-Shanusi, Supayacu-Aipena, and Cahuapanas-Sillay rivers. These communities are located in the provinces of Alto Amazonas and Datem del Marañon in the western part of Loreto, south of the Marañón River (Figure 1). Shawi historically lived inland from riverbanks, and more recently have settled in remote locations along the riverbanks. Families are located near the wife's parents, following a matrilocal social organization. Shawi relationships with the environment, and water in particular, continue to be grounded in spiritual cosmology, kinship, and reciprocity [58]. Shawi livelihoods tend to be gendered: slash and burn agriculture is practiced by both men and women, whereas hunting and small scale fishing are typically only conducted by men [59,60]. Small scale cultivation of yucca and banana provide the main source of income [55].

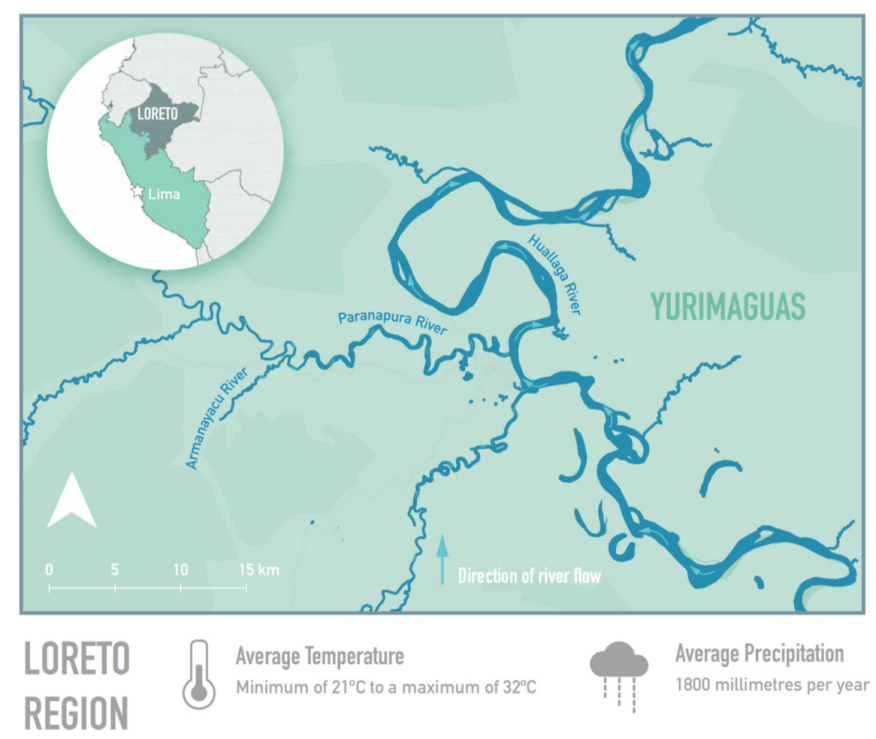

Figure 1. Map of the Armanayacu River, Yurimaguas, and surrounding area in the Loreto Region of the Peruvian Amazon. 
This study partnered with two Shawi Indigenous communities (Community A and Community B, de-identified for confidentiality) in the district of Balsapuerto, within the province of Alto Amazonas. These communities are located on both sides of the Armanayacu River, a tributary of the Amazon River via the Paranapura, Huallaga, and Marañón rivers. The communities are accessible by car and are approximately a two-hour drive from Yurimaguas, the nearest city. There is a health post located approximately 10 minutes away by car or one hour on foot. The road to the communities was constructed in 2010; prior to this, both communities were highly remote and accessible only by foot or boat. The improved road access has resulted in changes in lifestyle as new types of foods and sources of work have become increasingly available to community members. Road access has also facilitated deforestation and erosion of riverbanks by increasing access to timber resources, which has led to an associated increases in illegal timber harvesting [61,62].

\subsection{Project Background and Conceptual Framework}

The study design involved a concurrent mixed-methods quantitative and qualitative approach (Figure 2). In an effort to understand water security in an Indigenous context, this study approach followed the ecosystem approach to health (EcoHealth) framework, emphasizing the pillars of transdisciplinarity, participation, and equity [63-65]. This research is part of the Indigenous Health Adaptation to Climate Change (IHACC) Program (http://ihacc.ca/), which has been partnering in climate change research with Shawi since 2010; as such, this study builds from strong existing partnerships and relationships. In July 2015, the research team worked with the communities to develop this research study. Chiefs in both communities discussed the study and agreed to partner in the research. Data collection was conducted with local Indigenous partners between December 2015 and January 2016. Data were analyzed in collaboration with local Indigenous partners and results were validated by local Indigenous partners.

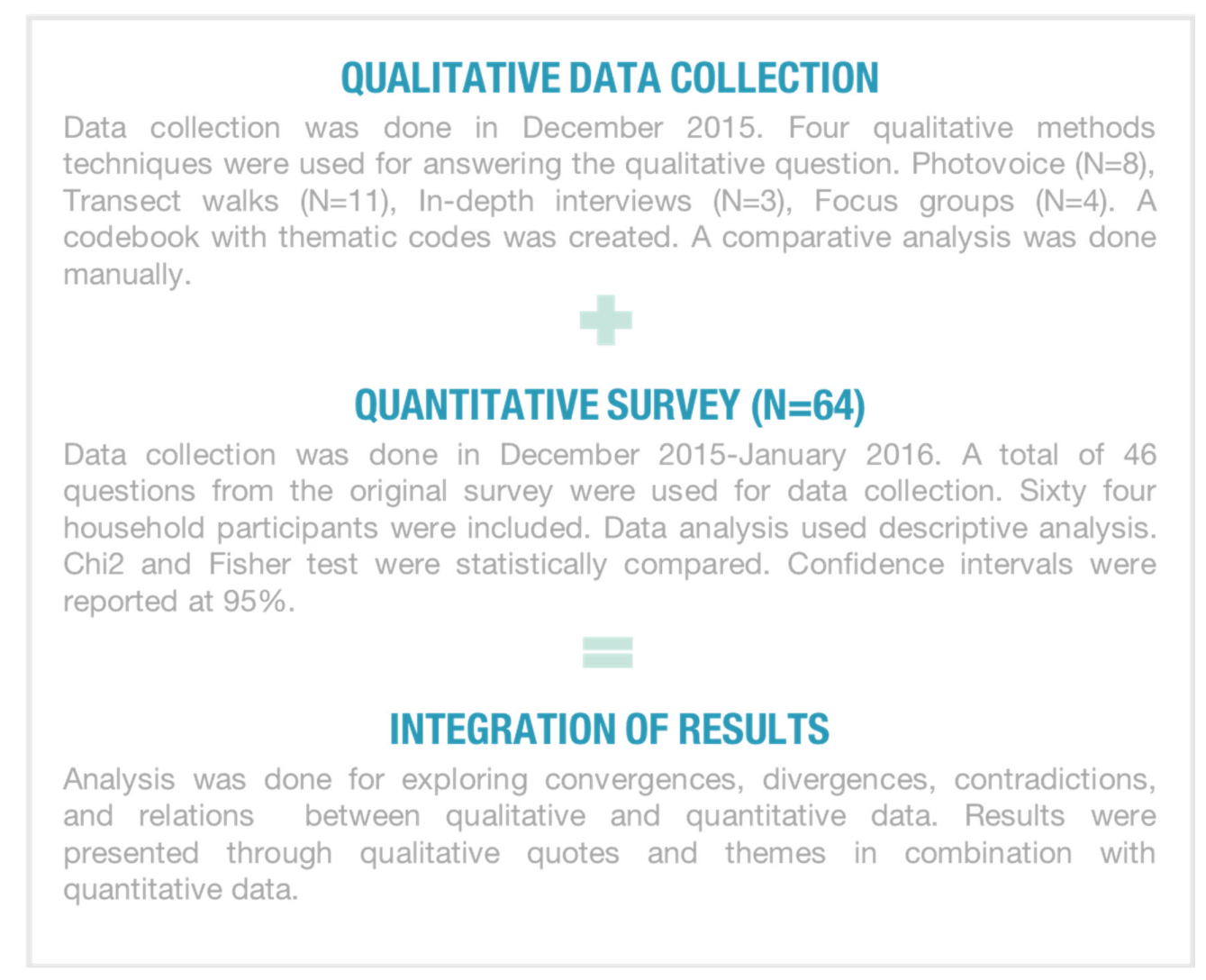

Figure 2. A model outlining the process of data collection and analysis for a concurrent mixed-methods study in partnership with two Shawi communities, Peruvian Amazon, 2015. 


\subsection{Qualitative Data Collection}

Four qualitative data collection methods were used in this study: PhotoVoice, focus group discussions, interviews, and transect walking paths. Purposeful sampling was used to identify participants for all qualitative data collection, in order to recruit individuals with specific knowledge about the research question. In all qualitative activities, participants were asked, in general, "What does water security mean for you and your community?". This question facilitated a deep exploration into the topic of water security in the communities, including the importance of water for daily uses, preservation of local ecosystems, and the impact of climate/weather change scenarios on water resources. Of note, the Shawi and Peruvian Spanish languages do not distinguish weather from climate (taweri in Shawi, or clima in Spanish). We did, however, ask participants to describe the season and timescale over which the changes in "clima" were observed, enabling us to begin to disentangle weather observations versus climate observations. While this meant it was challenging to distinguish between concepts of weather and climate in this study, our methods and results aligned with data reported by Hofmeijer et al. (2013) [55] in the same region, supporting the veracity of our results.

PhotoVoice is "a visual research methodology that puts cameras into the participants' hands to help them to document, reflect upon, and communicate issues of concern, while stimulating social change" [66]. PhotoVoice workshops were held only in Community A, where participants were trained in the use of cameras and the ethics of photography. Participants were provided with a digital camera to explore and photograph their daily activities in relation to water and water security. Participants were encouraged to take as many photos as needed to express their ideas. A workshop was held one week later to reflect on the photographs and develop and discuss recurring themes. For the discussion, each participant selected the three photos that resonated most with their ideas, feelings, and concerns about water security. A total of eight participants, including six adults (three females and three males) and two children (one boy and one girl) participated in PhotoVoice workshops in Community A.

Focus group discussions were conducted with adult participants from both communities and were stratified by gender. The intention of these dynamic group interviews was to collect group experiences and perceptions regarding water security. The focus group discussions lasted an average of 45 minutes. A total of seven women and eight men participated in the focus group discussions from Community A $(n=15)$, and seven women and eleven men participated in Community $B(n=18)$.

In-depth interviews were conducted with individuals who had been working locally for at least five years in fields related to climate change, Indigenous health, and/or water management. Questions were designed to explore individual experiences and perceptions based on their work in the fields of healthcare, educational programming, Indigenous issues, water, and/or climate change. In-depth interviews were conducted with four individuals (one female and three males) who had experience working with local institutions and communities.

Transect walking path activities involved "walking with participants along a path to explore Shawi connections to their environment, their sense of place, and their relationships with water" [58] as it relates to climate change and environmental changes $[67,68]$. These dynamic conversations were audio recorded and photographed with permission and informed consent. A total of five adult females and six adult males $(\mathrm{n}=11)$ from both communities participated in the transect walking path activities.

\subsection{Qualitative Data Analysis}

A total of $850 \mathrm{~min}$ of recorded conversation from PhotoVoice, focus group discussions, in-depth interviews, and transect walking paths were analyzed. In addition, 418 photographs from the transect walking paths and PhotoVoice activities were selected for thematic analysis. Data were analyzed using a constant comparative method based on a modified grounded theory approach [69-72]. This constant comparison method was used through all stages of the qualitative analysis. First, several data sources, including participant photographs, transcripts of discussions, and researcher notes were compiled [73-75]. Then, following data familiarization, theory-driven and data-driven (deductive and inductive) codes were developed, reflective memos were written, a thematic codebook was developed, 
and transcript text and photos were labeled. The data were analyzed using a team approach: that is, the codes and themes were developed, reviewed, discussed, selected, refined, and finalized by the research team [76-78]. The qualitative analysis was completed manually [79]. To ensure validity and authenticity of the results, the triangulation of data and analysis involved sharing information between team members (PTS, CW, SLH, EL, and GL) through an iterative process of comparing transcripts and member-checking so as to confirm the accuracy of research interpretation and the consistency of quality analysis, and to avoid language misinterpretation [80].

\subsection{Quantitative Data Collection and Analysis}

This study used data from three subsections of a census household survey: (i) sociodemographic data (e.g., age, sex, use of social programs); (ii) perceptions related to water and climate/weather change (e.g., quality of water resources, time of occurrence of changes in climate/weather, impact of changes in climate/weather on working activities, adaptation and response options); and (iii) economic activities (e.g., main labor activities during the year). Two Shawi researchers validated the Shawi language version of the questionnaire.

A cross-sectional household census survey was attempted in each community and questionnaires were administered to one adult member per household (i.e., an individual of $\geq 18$ years of age). Participants could choose to complete the questionnaire in their preferred language (Spanish or Shawi). Questionnaire data were collected by three local Indigenous researchers who were trained to administer the questionnaire. The questionnaire was completed using MAGPI software (http://home.magpi.com/) on mobile phones.

Data were analyzed using Stata/SE version 15.0 (StataCorp, Texas, US). Descriptive statistics (means, standard deviations, and proportions) were used to summarize variables. Depending on the nature of the independent variable, Fisher's exact or Student's t-tests were used to assess the independence of variables with the dichotomous variable "My family and community have been affected by changes in climate/weather". A p-value of $\leq 0.05$ was used to determine statistical significance.

\subsection{Ethical Considerations}

All participants in this study provided informed consent prior to participation. Two children (ages $>7$ years) provided written assent, and their parents provided informed consent. This study was approved by the Institutional Review Board of the Universidad Peruana Cayetano Heredia (approval number 65470), as well as Shawi community leaders. This study followed established ethical guidelines for research with Indigenous communities [65,81,82].

\section{Results}

\subsection{Shawi Climate Change Observations}

A total of 74 households were identified in the two communities and invited to participate in the survey; of these, 64 households completed the survey (household response rate: $86.5 \%$ ). The majority of household respondents were male $(80.9 \%)$, and the average age of participants was 40 years (Table 1 ).

Nearly $80 \%$ of households in the survey reported that seasonal climate/weather patterns had changed over time (Figure 3). The time period over which these reported changes were observed varied between household respondents, with some not recalling the time period of these changes $(28.0 \%)$, and others recalling changes occurring in the last 5 years $(18.0 \%)$, 10 years $(34.0 \%)$, or more than 15 years $(20.0 \%)$ (Table 2). Furthermore, qualitative participants suggested that the climate is indeed changing, affecting the local weather and creating new micro-climates. For example, one participant stated that "in the center of the nearby city of Yurimaguas, the temperature and rainy season patterns have changed dramatically over the last five to fifteen years" (I4).

In the survey, of those households who responded that they did observe seasonal and/or climate/weather patterns change over time (50/64 households), some stated that it rained less often 
in recent seasons $(4.0 \%)$, but when it did rain, the rainfall was more intense and resulted in flooding $(58.0 \%)$ (Table 2). Similarly, qualitative research participants described how annual rainfall levels appeared to have decreased in past years; however, during the rainy season, rainfall was more intense but shorter in duration. This increase in rainfall intensity was reported to increase the risk of flooding in the area. Indeed, flooding was an important concern in the Shawi communities. One recent flood in the area in 2014 was consistently described by qualitative research participants as worse than previous floods. These observations are consistent with other literature that describes a particularly bad flooding season in the Amazon, resulting in a state of emergency being declared in Bolivia and Peru [83].

Table 1. Description of household socio-demographic characteristics of survey participants in two Shawi communities, Peruvian Amazon $(n=64)$.

\begin{tabular}{ll}
\hline Sociodemographic Characteristics & n (\%) \\
\hline Number of household respondents in Community A & $52(81.2)$ \\
Number of household respondents in Community B & $12(18.8)$ \\
Household respondent was male & $51(80.9)$ \\
Age of respondent in years & $40.2(14.2)^{*}$ \\
Number of households receiving government cash transfer assistance & $53(82.8)$ \\
People per house & $5.1(2.1)^{*}$ \\
Adults per house & $2.3(0.9)^{*}$ \\
Children per house & $2.8(1.8)^{*}$ \\
\hline Labor activities & $\mathbf{n ~ ( \% )}$ \\
\hline Number of respondents participating in agriculture activities & $63(98.4)$ \\
Number of households with children participating in work activities & $47(73.4)$ \\
\hline \multicolumn{2}{r}{ * Mean (standard deviation) }
\end{tabular}

* Mean (standard deviation).

Climate/weather change observations and impacts reported by two Shawi communities in the Peruvian Amazon

Observed changes in river water over time $(n=64)$

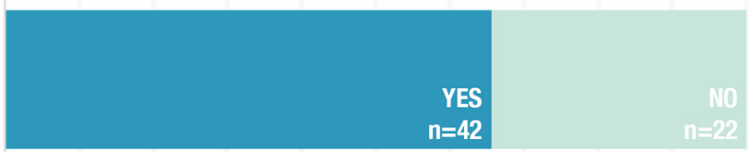

$n=42$

Observed changes in seasonal climate/weather patterns over time $(n=64)$

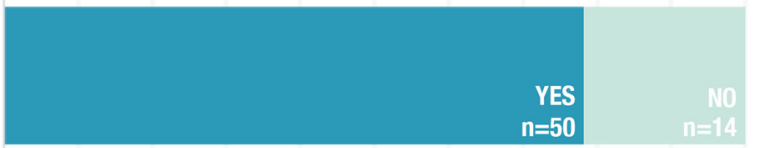

Changes in which resource most affects daily life and the health of your family? ( $n=64)$

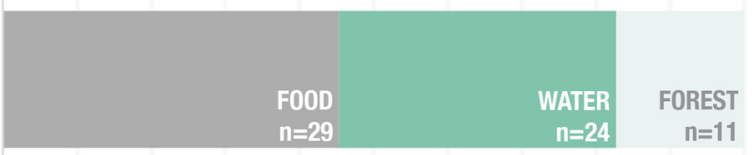

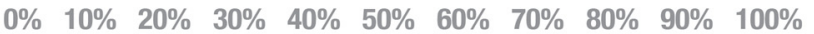

Figure 3. Climate/weather change observations and impacts as reported by two Shawi communities, Peruvian Amazon, 2015. 
Table 2. Climate/weather change observations, climate/weather change impacts on Shawi, and climate/weather change support/adaptation options reported in a household survey in two Shawi communities, Peruvian Amazon.

\begin{tabular}{|c|c|}
\hline Climate/Weather Change Observations & n $(\%)$ \\
\hline \multicolumn{2}{|c|}{$\begin{array}{l}\text { Of those who observed changes in seasonal climate/weather patterns over time }(n=50) \text { : } \\
\text { Reported time period of observed changes }\end{array}$} \\
\hline 5 years & $9(18.0)$ \\
\hline 10 years & $17(34.0)$ \\
\hline$>15$ years & $10(20.0)$ \\
\hline Unsure & $14(28.0)$ \\
\hline \multicolumn{2}{|c|}{ Observed changes in seasonal and/or climate/weather patterns over time } \\
\hline Rains less often & $2(4.0)$ \\
\hline Rain is more intense, longer in duration, and/or results in flooding & $29(58.0)$ \\
\hline Air temperature is warmer & $4(8.0)$ \\
\hline No clear changes observed & $15(30.0)$ \\
\hline \multicolumn{2}{|l|}{ Labor activities were affected by changes in climate/weather } \\
\hline No & $3(6.0)$ \\
\hline Yes & $47(94.0)$ \\
\hline Water change observations & n (\%) \\
\hline \multicolumn{2}{|l|}{$\begin{array}{l}\text { Of those who observed changes in river water over time }(n=42) \text { : } \\
\text { Types of observed changes in river water overtime }\end{array}$} \\
\hline The water level in the river is higher & $35(83.3)$ \\
\hline The water level in the river is lower & $5(11.4)$ \\
\hline The river water is dirtier and sandier & $2(4.8)$ \\
\hline Climate/weather change preparedness/adaptation options & n (\%) \\
\hline \multicolumn{2}{|c|}{$\begin{array}{l}\text { Household respondent reported that their family or community had received support to } \\
\text { respond to climate/weather events (e.g., government, NGO, } \mathrm{n}=64 \text { ) }\end{array}$} \\
\hline No & $54(84.4)$ \\
\hline Yes & $10(15.6)$ \\
\hline \multicolumn{2}{|c|}{$\begin{array}{l}\text { Household respondent reported that measures, at the household or community level, were } \\
\text { taken to respond to climate/weather events }(n=64)\end{array}$} \\
\hline No & $61(95.3)$ \\
\hline Yes & $3(4.7)$ \\
\hline
\end{tabular}

\subsection{Climate/Weather Change Impacts on Shawi}

Most households in the survey who reported observed changes in seasonal climate/weather patterns over time reported that their family and community were already affected by these changes $(86 \%)$. Among survey respondents who observed changes in seasonal climate/weather patterns over time, $76.0 \%(n=38)$ of households reported changes in community A, while $24.0 \%(n=12)$ reported changes in community B (Table 3 ).

Of the household survey respondents who observed changes in seasonal climate/weather patterns over time, $40.8 \%$ considered changes in river water to be an important concern for them and/or their families. The Armanayacu River was the main water source for residents in both communities. A large proportion of household survey respondents who reported climate and seasonal change impacts on their family and community also reported that there were changes in water from the Armanayacu River over past years $(\mathrm{p}=0.012$; Table 3$)$. More than half $(58.0 \%)$ of the household survey respondents who observed changes in river water reported that the water level in the river was higher than in previous years (Table 3).

According to qualitative research participants, water coming from the Armanayacu River during the rainy season was dirtier and more turbid than in the past, which they believed was caused by riverbank erosion due to deforestation, as well as climate-related changes in seasonal rainfall frequency and intensity. When the river was filled with leaves and sediment, qualitative research participants reported that the water became stagnant, further contributing to water temperature 
increases. In addition, debris and sediment led to a "reddish" color in the water, which contributed to the observation that the river water was "dirty". Participants said that they were more cautious about bathing in the river after heavy rainfall, as water currents could become dangerously strong, bringing along unseen debris that could harm bathers. During the dry season, qualitative research participants described the river water as typically clearer and less turbid; however, participants reported that the low water levels and increased sediment in the river resulted in new beaches along the riverbank (Figure 4). Some community members reflected on how deeply these environmental changes affected their relationship with water and their daily activities, including water collection and bathing.

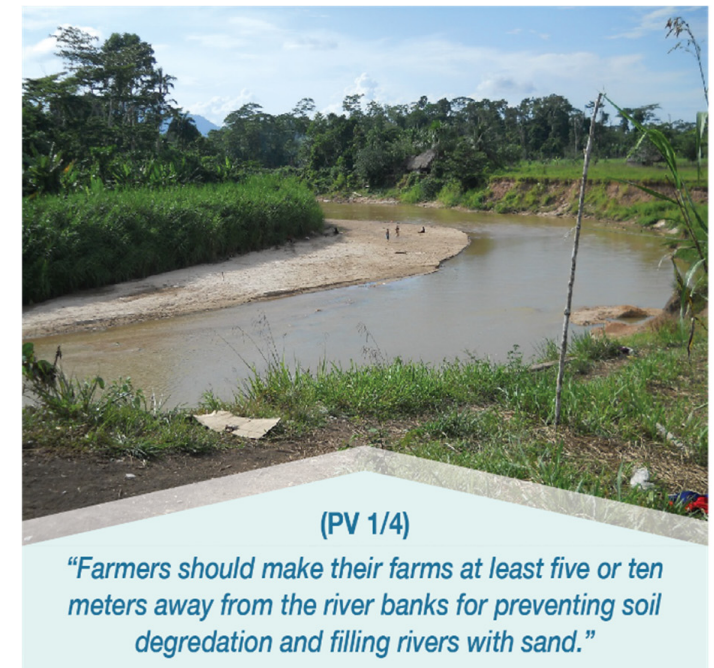

(a)

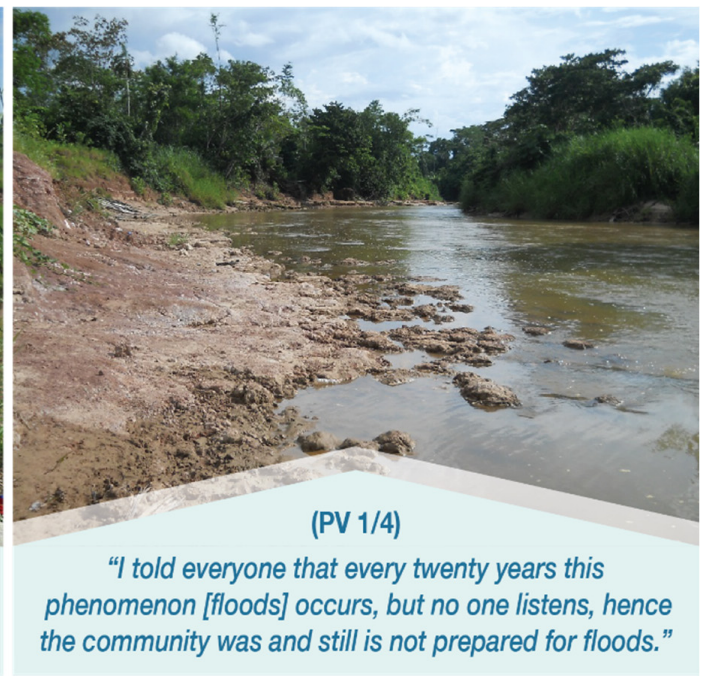

(b)

Figure 4. Photographs and quotations from PhotoVoice participants relating to riverbank changes, degradation, and flooding in two Shawi communities, Peruvian Amazon, 2015. (a): A participant photo showing a sandy riverbank; (b): A participant photo representing how riverbank degradation can increase risk of flooding.

Also of concern among Shawi were climate/weather-related changes in food security. Of the household survey respondents who perceived that their family and community were affected by changes in climate/weather, $38.8 \%$ considered related changes in food resources to be an important concern for them and/or their families. Qualitative research participants explained that flooding, in particular, affected the community's sowing practices, occasionally causing some individuals to lose all the work they put into planting and maintaining their field.

Nearly all households in the survey reported that changes in climate/weather had affected their labor activities (94\%) (Table 2). Almost all community members practiced subsistence agriculture throughout the year (Figure 5). Trees are cut down to prepare the ground for planting from March to July. Then, crops are harvested from July to December, with crop sales taking place from October to February. Other labor activities reported in the communities included crafting, fishing, and hunting. Approximately three quarters of respondents indicated that children in the community assisted with work activities outside of school (Table 1). In addition to agriculture and other labor activities, most respondents (82.8\%) reported that their family currently benefited from the social program "Juntos", which is a government cash transfer program for families facing extreme poverty. 


\section{PROPORTION (\%)}

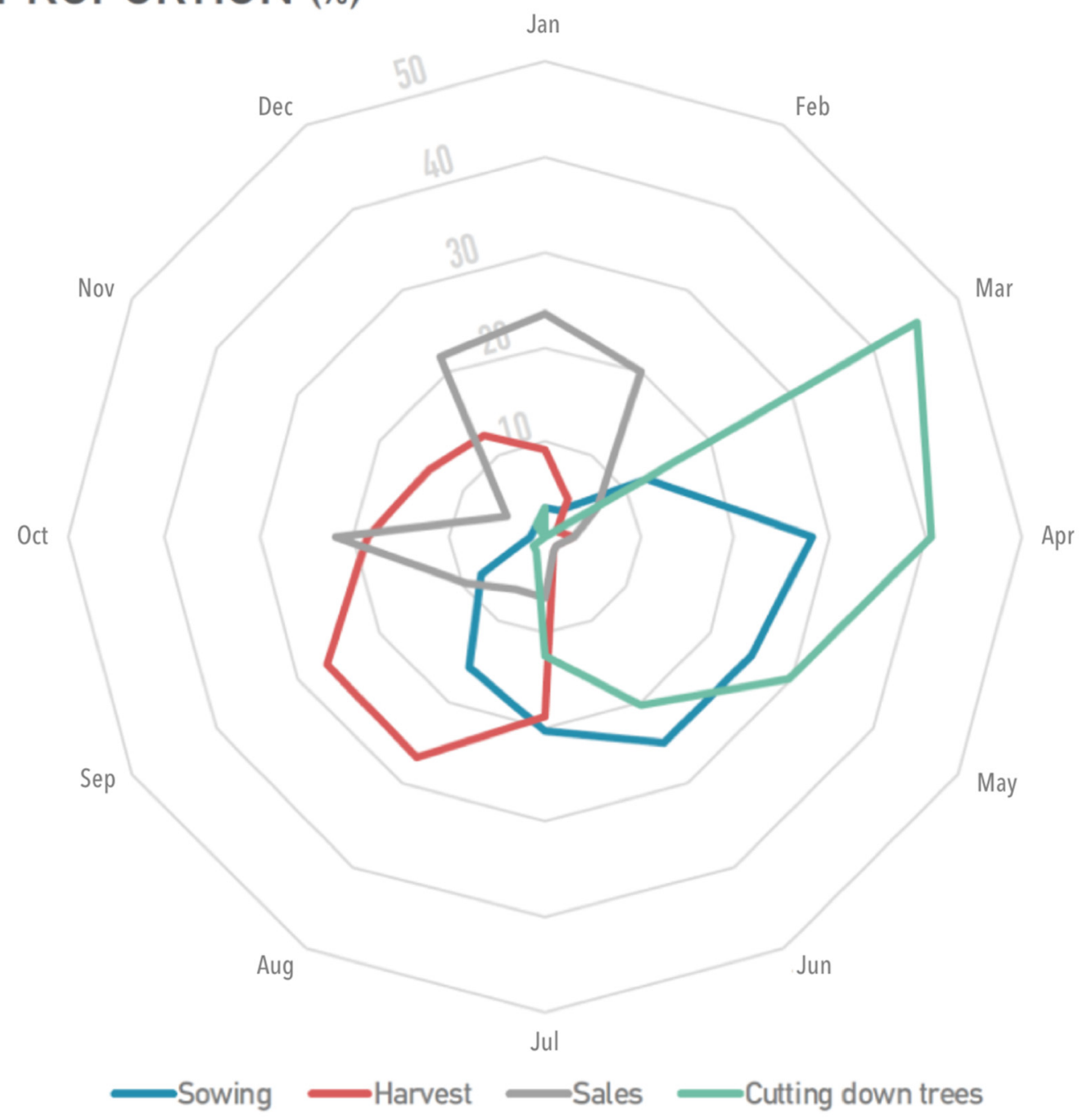

Figure 5. Annual timeline of agricultural activities reported by Shawi respondents $(\mathrm{n}=64)$, Peruvian Amazon.

\subsection{Preparedness, Adaptation Options, and Challenges}

No households in the survey reported community-level plans for responding to extreme weather events, and the community had not received and did not expect assistance from the government when such events occurred. This lack of preparedness was described by multiple qualitative research participants when reflecting on a particularly bad flood in 2014, during which approximately $50 \mathrm{~cm}$ of water accumulated in the communities as a result of a single rainfall event over one night. Water covered the central field of one community, even reaching the upper hills. Qualitative research participants described the rain as "silent" and "constant", occurring during the night while the community was sleeping. Residents reported that they were neither alerted nor prepared for such an extreme rainfall event. Because they were not adequately prepared to deal with flooding, community members explained that they were not able to assist each other in the immediate aftermath of the event. Furthermore, participants explained that timely support did not arrive from outside the community. The authorities in the communities travelled to Yurimaguas seeking support from the Defensa Civil (The National Institute of Civil Defense, a government-sponsored citizen protection service for natural disasters), and radio journalists arrived on the scene shortly thereafter. After several months, municipal authorities arrived to carry out a census of the flood victims and initiate the process of delivering 
support. Some community members recalled that the last similarly catastrophic flood event happened about twenty years ago (Figure 4).

Table 3. Comparing proportions of households who reported observed changes in climate/weather over time to socio-demographic variables, weather-related variables, and water-related variables $(n=64)$.

\begin{tabular}{|c|c|c|c|}
\hline & $\begin{array}{c}\text { Household Did Not Report } \\
\text { Observed Changes in } \\
\text { Seasonal Weather Patterns } \\
\text { over Time } \\
\mathrm{n}=14\end{array}$ & $\begin{array}{c}\text { Household Reported } \\
\text { Observed Changes in } \\
\text { Seasonal Weather } \\
\text { Patterns over Time } \\
n=50\end{array}$ & $P^{*}$ \\
\hline $\begin{array}{l}\text { Sociodemographic Variables of } \\
\text { Respondent }\end{array}$ & n $(\%)$ & n (\%) & \\
\hline \multicolumn{4}{|l|}{ Community } \\
\hline$A$ & $14(100.0)$ & $38(76.0)$ & \multirow[b]{2}{*}{0.054} \\
\hline$B$ & $0(0.0)$ & $12(24.0)$ & \\
\hline \multicolumn{4}{|l|}{ Gender } \\
\hline Male & $10(71.4)$ & $41(82.0)$ & \multirow{2}{*}{0.457} \\
\hline Female & $4(28.6)$ & $9(18.0)$ & \\
\hline \multicolumn{4}{|l|}{ Weather-related variables } \\
\hline \multicolumn{4}{|c|}{ Household, family, or community received support to respond to climate events } \\
\hline No & $14(100.0)$ & $38(76.0)$ & \multirow{2}{*}{0.054} \\
\hline Yes & $0(0.0)$ & $12(24.0)$ & \\
\hline \multicolumn{4}{|c|}{ Changes in resources that would most affect daily life and the health of your family } \\
\hline Changes or deterioration in water & $3(21.4)$ & $21(42.0)$ & \multirow{3}{*}{0.371} \\
\hline Changes or deterioration in forest & $3(21.4)$ & $8(16.0)$ & \\
\hline Changes or deterioration in food & $8(57.2)$ & $21(42.0)$ & \\
\hline \multicolumn{4}{|l|}{ Water-related observations ** } \\
\hline \multicolumn{4}{|c|}{ Observed changes in river water over time } \\
\hline No & $9(64.3)$ & $13(26.0)$ & \multirow{2}{*}{0.012} \\
\hline Yes & $5(35.7)$ & $37(74.0)$ & \\
\hline \multicolumn{4}{|l|}{ Observed changes in river water } \\
\hline The water level in the river is higher & $6(42.9)$ & $29(58.0)$ & \multirow{4}{*}{0.578} \\
\hline The water level in the river is lower & $1(7.1)$ & $4(8.0)$ & \\
\hline The river water is dirtier and sandier & $0(0.00)$ & $2(4.0)$ & \\
\hline No clear changes observed & $7(50.0)$ & $15(30.0)$ & \\
\hline
\end{tabular}

Many participants described the impacts of deforestation on the river system. While deforestation was not explicitly linked to climate/weather change, the resulting environmental degradation was reported as posing challenges for effective adaptation. For instance, participants reported that in previous years there were many trees that lined the riverbank, which shaded the river and provided support and structure for the riverbanks. However, recently, many trees had been cut down to make fields for farming, and the river no longer received as much shade. Additionally, when the trees were cut down, it caused the river edges to erode and collapse more easily. As one PhotoVoice participant explained, "Years ago, around the edge of the riverbank, there were large trees and clean water. Some people cut down the trees to build farms near the ravines, but now the riverbanks have no resistance and fall" (PV7). These impacts of deforestation on the river system are then exacerbated by climate-related changes in rainfall patterns and flooding, including accelerated warming of water temperatures (due to warmer weather, exacerbated by fewer trees for shading) and increased erosion and water turbidity (due to increased intense rainfall and flooding, exacerbated by deforestation impacts on riverbank stability). As such, an important adaptation strategy identified by community members was reforestation of the riverbank; as one PhotoVoice participant stated, "I believe they should plant resistant trees at the edge of the riverbank, to give shade and help the river not be refilled with sand and stay deeper" (PV7). A transect walk participant recalled: 
"Sometimes you feel very warm and you want to bathe in the river, but the water is too hot. It is more refreshing at night around nine or ten. This did not happen before; there were more trees beside the riverbank and everything was different. We have done this to the environment. It would be nice if we could reforest and plant large trees". (TWP5)

In order to prevent further degradation of the tributaries of Amazonian rivers, community members wanted to draw the attention of government authorities to the challenges of environmental protection and water safety. In the focus group discussions, men were particularly eager to engage community authorities and municipal government personnel in water-related programs along the Armanayacu River:

"We must call the authorities from each community. Here we are twenty communities that live in the Armanayacu area. We should all meet in a community and talk about how to get more water care. We can have a talk about the best care of water and water safety, such as not fishing, not throwing garbage in the river, not cutting trees for clearing chacras [farms] along the river ... for taking care of fresh water so it is not like this in these times ... as the water is warmer, right now the water is getting too hot... That is why all community authorities must talk with the [municipal] authorities to teach us about how not to contaminate the river". (FGM1)

Another transect walk participant conveyed a similar argument:

"[We should] ask for educational training in water and river contamination, fishing, and avoiding throwing dead rotten animals into the river. [Government authorities] should train community authorities, so they can teach our community information about well-being". (TWP10)

In addition to changes in river water levels, changes were also observed in groundwater, and participants noted the need to begin planning for adaptation. As one interview participant recalled:

"It feels as if we are squeezing the last drops of milk from the cow [referencing lack of groundwater collected via wells] ... I do not know what the situation will be like here in the next five years, we have to be planning for the long term, not just the next twenty years ... This is a very deep problem at a health and educational level, but there are no government plans or policies". (I3)

This participant also identified the aguaje (Mauritia flexuosa) and the pijuayo (Bactris gasipaes) as very important palm trees that act as indirect indicators of groundwater availability because they store large quantities of groundwater. Participants explained that declining groundwater levels could indicate that the trees cannot access the amount of water necessary for them to thrive, which could reduce their abundance. Participants explained that examining these trees provides one way to monitor variations in groundwater levels due to climate change. As one participant stated:

"There is a tree called aguaje that keeps inside enough water, it is an indirect way to monitor the amount of underground water. Unfortunately, the aguaje has diminished lately. This could be that the aguaje is indicating to me that underground water is missing". (I4)

Participants explained that recently, however, these trees were being cut down. As such, variations in groundwater levels are now challenging monitoring in this traditional way.

\section{Discussion}

This study used mixed methods to examine how climate and long-term weather changes impact water systems based on Indigenous Shawi knowledge, characterized how these changes have impacted 
livelihoods, and explored adaptation and preparedness for future climatic events in two Shawi Indigenous communities in the Peruvian Amazon. Most participants reported that within the last 15 years there were observable changes in the seasons, including less rain but more intense precipitation events over time. Changes in weather and climate were particularly noticeable when those changes affected the labor activities of community members. Additionally, flooding was identified as an important concern for these two Shawi communities. Community members also described how non-climatic factors, such as deforestation, were exacerbating climate/weather change impacts and challenging adaptation. The changes in weather and seasonal patterns are reflected in climate projections for the Peruvian Amazon, which include a projected increase of $1.5^{\circ} \mathrm{C}$ in temperature associated with loss of forested areas, a decrease in precipitation, and more prevalent drought and flooding conditions $[19,22,35,37,61,84-86]$.

Non-climatic factors, including deforestation, increased the vulnerability of water systems to climatic change for the Shawi, and undermined adaptation options. The Amazon Basin spans many South American countries, including Venezuela, Colombia, Ecuador, Peru, Bolivia, Brazil, French Guiana, Suriname, and Guyana; it is a highly biodiverse ecosystem that covers approximately one-third of the land surface of South America. The Amazon consists primarily of rainforest and contains over 1000 tributaries of the Amazon River. Driven by a number of factors, such as population growth $[87,88]$, since 2000, almost 30 million hectares of primary forest have been deforested, which is an area equal to the geographic size of Ecuador [89]. Deforestation has far-reaching impacts on the Amazon Basin ecosystem; for example, it has resulted in increased land and riverbank erosion, which has triggered flooding in the lower Amazon and negatively impacted the quality and quantity of surface water sources $[90,91]$. Continued deforestation may lead to an "Amazon tipping point", after which the ecological system could be irreversibly altered [62,92-94]. Projection models using data from the past three decades in the area suggest that large-scale deforestation could substantially impact the water cycle, resulting in a warmer climate with a decrease in precipitation of up to $40 \%$ [20]. For the Shawi, these changes have already had impacts on their water security.

Shawi described how water-related impacts from climate/weather changes impacted agricultural labor activities and food security. Similarly, Sherman et al. (2015) [56] found that Indigenous Shipibo communities near the Peruvian city of Pucallpa (Panaillo) were also experiencing environmental changes such as high impact flooding and agriculture-related deforestation. Shipibo community members described a relationship between these factors, with participants explaining how deforestation along the riverbanks was affecting the river water by increasing the risk of floods and worsening water quality [56]. Furthermore, complex relationships between deforestation, development projects such as road construction, and climate change can result in negative environmental and social impacts [92,95]. For example, a study conducted in the Peruvian Amazon found that road construction was having negative impacts on drinking water quality for nearby Indigenous communities [96]. Similar impacts have been reported elsewhere in the Amazon; for example, Reyes-Garcia et al. (2014) [97] described the complex governance, cultural, and socio-economic impacts of expanded road networks and resource development activities for Tsiname Indigenous communities in Bolivia.

In Peru, government policies for adaptation to the impacts of climate change focus on strengthening resilience and reducing vulnerability in diverse communities and systems; for example, the Peruvian Ministry of Environment prioritized the implementation of national adaptation plans [98]. Despite these national legislations, there are still several gaps in the country's preparations for extreme weather events, forest fires, deforestation, or future climate change threats, specifically concerning rural and remote populations and Indigenous peoples [21,45,49]. Indeed, Shawi community members clearly indicated that they were not prepared for the catastrophic flooding event in 2014, and they received markedly little support from the government or NGOs. Given that projections show an increase in the number of extreme flooding events, improving preparedness will be an important area for climate change response and adaptation. Previous work done in the Peruvian Amazon by Hofmeijer et al. (2013) [55] and Sherman et al. (2015) [56] also found that potentially vulnerable communities lacked 
appropriate planning and resources to manage the impacts of severe weather events. While these past studies focused on general health exposures and food insecurity, we focused on water security and identified similar vulnerabilities. This evidence base can be used to better understand the vulnerabilities of different communities to climate change, and inform climate change adaptation strategies and enhance preparedness.

A strength of this analysis was the use of a mixed-methods approach under an EcoHealth research framework. The approach in this study was community-based, and the principles of participation, transdisciplinarity, and equity were incorporated into the study design, data collection, and analysis phases of the research process. These principles enabled us to gain a broad understanding of climate and environmental changes and the subsequent impacts on water security for the Shawi communities who participated in the study. Although this study collected important baseline data on a variety of water- and weather-related variables, it is important to emphasize the diversity within and among Indigenous peoples. As such, caution should be used in extrapolating our research results to other Indigenous peoples and communities.

\section{Conclusions and Recommendations}

Shawi in this study described environmental changes as deeply affecting their relationships with water, provoking community calls for climate change adaptation efforts. Riverbank degradation and the resultant changes in river water turbidity and temperature were major concerns in the communities. Community members observed changes in seasonal weather patterns, with less rain but more intense precipitation events occurring over time, which posed an increased risk of flooding. These changes affected labor activities, families, and communities.

This study highlights how non-climatic drivers, such as deforestation along riverbanks, exacerbates climate change impacts on water systems and communities, thereby increasing vulnerability and undermining adaptation options. The changes experienced by the communities in this study, as well as other communities in the Peruvian Amazon, are projected to worsen as climate change progresses. Local adaptation policies for environmental changes, extreme weather events, and climate change risks for Shawi communities should be implemented at the local and regional level. Strict regulations aimed at reducing deforestation should be included as part of national climate change mitigation and adaptation policies.

Moving forward, subsequent research should focus on systematically monitoring weather conditions at the local level, including the use of community-based monitoring programs to monitor and respond to changes precipitation levels, changes in temperature, deforestation, changes in land use, and riverbank erosion. These community-based data and resources would provide important baseline information, contribute to more accurate climate projections, and support community resilience to climate change in rural areas of the Peruvian Amazon.

Author Contributions: Conceptualization, P.A.T.-S., S.L.H., and IHACCR.T.; methodology, P.A.T.-S. and S.L.H.; formal analysis, P.A.T.S., C.J.W., S.L.H., G.L.; resources, P.A.T.-S., C.P.C., P.J.G., J.D.F., IHACCR.T., S.L.H.; writing—original draft preparation, P.A.T.-S.; writing—review and editing, P.A.T.-S., C.J.W., C.P.C., P.J.G., J.D.F., IHACCR.T., S.L.H.; visualization, P.A.T.-S. and C.J.W.; supervision, C.P.C. and S.L.H.; project administration, P.A.T.-S., C.J.W., C.P.C., P.J.G., E.L., G.L., J.D.F., IHACCR.T., S.L.H.; funding acquisition, P.A.T.-S., C.P.C., P.J.G., J.D.F., IHACCR.T., S.L.H. All authors have read and agreed to the published version of the manuscript.

Funding: This research was supported by the Indigenous Health Adaptation to Climate Change (IHACC) Program (http://ihacc.ca/), through funding from the Canadian Institutes of Health Research, and The International Development Research Center's International Research Initiative on Adaptation to Climate Change. Funding was also provided by a 2016 Ekosanté Internship Award, a 2015 UNESCO/Keizo Obuchi Research Fellowship, and a 2014 Ekosanté Professional Development Award.

Acknowledgments: We would like to thank all the people in the Shawi communities for participating in this study. Special thanks to Tito Chanchari, Elvis Lancha, and Desiderio Tangoa for their assistance with field research; to Mark Andrachuk for assistance with initial data analysis; and to Isaac Bell, Alex Sawatzky, and Rachael Vriezen for editorial support.

Conflicts of Interest: The authors declare no conflict of interest. 


\section{References}

1. Shukla, P.R.; Skea, J.; Slade, R.; van Diemen, R.; Haughey, E.; Malley, J.; Pathak, M.; Pereira, J.P. Foreword Technical and Preface. (Climate Change and Land: An IPCC Special Report on Climate Change, Desertification, Land Degradation, Sustainable Land Management, Food Security, and Greenhouse Gas Fluxes in Terrestrial Ecosystems); IPCC: Geneva, Switzerland, 2019; pp. 35-74.

2. Diaz, S.; Settele, J.; Brondizio, E.; Ngo, H.T.; Gueze, M.; Agard, J.; Arneth, A.; Balvanera, P.; Brauman, K.; Butchart, S.; et al. Summary for Policymakers of the Global Assessment Report on Biodiversity and Ecosystem Services of the Intergovernmental Science-Policy Platform on Biodiversity and Ecosystem Services. Available online: https://www.ipbes.net/sites/default/files/downloads/spm_unedited_advance_for_posting_htn.pdf (accessed on 15 March 2020).

3. IPCC. IPCC special report on climate change and land-Summary for policy makers. In Research Handbook on Climate Change and Agricultural Law; Edward Elgar Publishing: Cheltenham, UK, 2019; pp. 423-449.

4. Wang, H.; Horton, R. Tackling climate change: The greatest opportunity for global health. Lancet 2015, 386, 1798-1799. [CrossRef]

5. Woodward, A.; Smith, K.R.; Campbell-Lendrum, D.; Chadee, D.D.; Honda, Y.; Liu, Q.; Olwoch, J.; Revich, B.; Sauerborn, R.; Chafe, Z.; et al. Climate change and health: On the latest IPCC report. Lancet 2014, 383, 1185-1189. [CrossRef]

6. United Nations. UN-Water Climate Change Adaptation: The Pivotal Role of Water; United Nations: New York, NY, USA, 2010; pp. 1-18.

7. The, L. Health systems for prosperity and solidarity: Tallinn 2018. Lancet 2018, 391, 2475. [CrossRef]

8. Watts, G. The health benefits of tackling climate change-An executive summary for the lancet series. 2009. Available online: https:/www.thelancet.com/pb/assets/raw/Lancet/stories/series/health-and-climate-change. pdf (accessed on 20 March 2020).

9. Gill, M.; Stott, R. Health professionals must act to tackle climate change. Lancet 2009, 374, $1953-1955$. [CrossRef]

10. Watts, N.; Amann, M.; Arnell, N.; Ayeb-Karlsson, S.; Belesova, K.; Boykoff, M.; Byass, P.; Cai, W.; Campbell-Lendrum, D.; Capstick, S.; et al. The 2019 report of the lancet countdown on health and climate change: Ensuring that the health of a child born today is not defined by a changing climate. Lancet 2019, 394, 1836-1878. [CrossRef]

11. UNU-INWEH. UN-Water Water Security \& the Global Water Agenda; UNU-INWEH: Hamilton, ON, Canada, 2013; ISBN 9789280860382.

12. Watts, N.; Adger, W.N.; Agnolucci, P. Changement climatique: Agir au nom de la santé publique. Environ. Risques Sante 2015, 14, 466-468.

13. Wojtkowiak, S. Climate Change, Water and Food Security; Food and Agriculture Organization of the United Nations: Rome, Italy, 2011.

14. Karen, B. Water security: Research challenges and opportunities. Science 2012, 337, 914-915.

15. Cook, B.; Zeng, N.; Yoon, J.-H. Will amazonia dry out? Magnitude and causes of change from IPCC climate model projections. Earth Interact. 2012, 16, 1-27. [CrossRef]

16. Marengo, J.A.; Chan, S.; Gillian, C.; Lincoln, K.; Jose, M.A.; Chagas, D.J.; Gomes, J.L.; Bustamante, J.F.; Tavares, P. Development of regional future climate change scenarios in South America using the Eta CPTEC/HadCM3 climate change projections: Climatology and regional analyses for the Amazon, Sao Francisco and the Parana River basins. Clim. Dyn. 2012, 38, 1829-1848. [CrossRef]

17. Kovats, R.S.; Campbell-Lendrum, D.; Matthies, F. Climate change and human health: Estimating avoidable deaths and disease. Risk Anal. 2005, 25, 1409-1418. [CrossRef]

18. Langerwisch, F.; Rost, S.; Gerten, D.; Poulter, B.; Rammig, A.; Cramer, W. Potential effects of climate change on inundation patterns in the Amazon Basin. Hydrol. Earth Syst. Sci. 2013, 17, 2247-2262. [CrossRef]

19. Duffy, P.B.; Brando, P.; Asner, G.P.; Field, C.B. Projections of future meteorological drought and wet periods in the Amazon. Proc. Natl. Acad. Sci. USA 2015, 112, 13172-13177. [CrossRef] [PubMed]

20. Marengo, J.; Nobre, C.A.; Betts, R.A.; Cox, P.M.; Sampaio, G.; Salazar, L. Global Warming and Climate Change in Amazonia: Climate-Vegetation Feedback and Impacts on Water Resources; American Geophysical Union: Washington, DC, USA, 2009; pp. 273-292. [CrossRef] 
21. Bodmer, R.; Mayor, P.; Antunez, M.; Chota, K.; Fang, T.; Puertas, P.; Pittet, M.; Kirkland, M.; Walkey, M.; Rios, C.; et al. Major shifts in Amazon wildlife populations from recent intensification of floods and drought. Conserv. Biol. 2018, 32, 333-344. [CrossRef] [PubMed]

22. Eguiguren-Velepucha, P.A.; Chamba, J.A.M.; Aguirre Mendoza, N.A.; Ojeda-Luna, T.L.; Samaniego-Rojas, N.S.; Furniss, M.J.; Howe, C.; Aguirre Mendoza, Z.H. Tropical ecosystems vulnerability to climate change in southern Ecuador. Trop. Conserv. Sci. 2016, 9. [CrossRef]

23. Prevedello, J.A.; Winck, G.R.; Weber, M.M.; Nichols, E.; Sinervo, B. Impacts of forestation and deforestation on local temperature across the globe. PLoS ONE 2019, 14, 1-18. [CrossRef] [PubMed]

24. Brookes, J.D.; Carey, C.C. Ensure availability and sustainable management of water and sanitation for all. UN Chron. 2015, 51, 15-16. [CrossRef]

25. Chan, M. Achieving a cleaner, more sustainable, and healthier future. Lancet 2015, 386, e27-e28. [CrossRef]

26. McGinnis, S.M.; McKeon, T.; Desai, R.; Ejelonu, A.; Laskowski, S.; Murphy, H.M. A systematic review: Costing and financing ofwater, sanitation, and hygiene (WASH) in schools. Int. J. Environ. Res. Public Health 2017, 14, 442. [CrossRef]

27. Myers, S.S.; Patz, J. Emerging Threats to Human Health from Global Environmental Change. Annu. Rev. Environ. Rsour. 2009, 34, 223-252. [CrossRef]

28. Parkinson, J. A Review of the Evidence Base for WASH Interventions in Emergency Responses/Relief Operations-Executive Summary; Atkins: Epsom, UK, 2009; pp. 1-51.

29. Sapkota, A.R. Water reuse, food production and public health: Adopting transdisciplinary, systems-based approaches to achieve water and food security in a changing climate. Environ. Res. 2019. [CrossRef]

30. Curriero, F.C.; Patz, J.A.; Rose, J.B.; Lele, S. The association between extreme precipitation and waterborne disease outbreaks in the United States, 1948-1994. Am. J. Public Health 2001, 91, 1194-1199. [CrossRef] [PubMed]

31. Wright, C.J.; Sargeant, J.M.; Edge, V.L.; Ford, J.D.; Farahbakhsh, K.; RICG; Shiwak, I.; Flowers, C.; IHACC Research Team; Harper, S.L. Water quality and health in northern Canada: Stored drinking water and acute gastrointestinal illness in Labrador Inuit. Environ. Sci. Pollut. Res. 2018. [CrossRef] [PubMed]

32. Patz, J.A.; Frumkin, H.; Holloway, T.; Vimont, D.J.; Haines, A. Climate change: Challenges and opportunities for global health. J. Am. Med. Assoc. 2014, 312, 1565-1580. [CrossRef] [PubMed]

33. Santa Cruz, F.; Mujica, M.; Álvarez, J.; Leslie, J. Informe Sobre Desarrollo Humano Perú 2013. Cambio Climático Y Territorio: Desafíos Y Respuestas Para Un Futuro Sostenible; Programa de las Naciones Unidas para el Desarrollo PNUD: Lima, Perú, 2013.

34. Marengo, J.A.; Jones, R.; Alves, L.M.; Valverde, M.C. Future change of temperature and precipitation extremes in South America as derived from the PRECIS regional climate modeling system. Int. J. Climatol. 2009, 29, 2241-2255. [CrossRef]

35. Marengo, J.A.; Tomasella, J.; Soares, W.R.; Alves, L.M.; Nobre, C.A. Extreme climatic events in the Amazon basin. Theor. Appl. Climatol. 2012, 107, 73-85. [CrossRef]

36. Lavado Casimiro, W.S.; Labat, D.; Guyot, J.L.; Ardoin-Bardin, S. Assessment of climate change impacts on the hydrology of the Peruvian Amazon-Andes basin. Hydrol. Process. 2011, 25, 3721-3734. [CrossRef]

37. Marengo, J.A.; Tomasella, J.; Alves, L.M.; Soares, W.R.; Rodriguez, D.A. The drought of 2010 in the context of historical droughts in the Amazon region. Geophys. Res. Lett. 2011, 38, 1-5. [CrossRef]

38. Crane, R.J.; Jones, K.D.J.; Berkley, J.A. Environmental enteric dysfunction: An overview. Food Nutr. Bull. 2015, 36. [CrossRef]

39. UN News. UN Adopts New Global Goals, Charting Sustainable Development for People and Planet by 2030. Available online: https://news.un.org/en/story/2015/09/509732-un-adopts-new-global-goals-chartingsustainable-development-people-and-planet (accessed on 15 March 2020).

40. Ki-moon, U.N.S.B. Water and sanitation: Addressing inequalities. Lancet 2014, 383, 1359.

41. McLeman, R.; Smit, B. Migration as an adaptation to climate change. Clim. Chang. 2006, 76, 31-53. [CrossRef]

42. Huamán Rodríguez, G. Los Pueblos Indígenas de la Amazonía Peruana: Pueblos Indígenas e Inversión en el Territorio Ancestral; Peter Lang: Bern, Switzerland, 2016; ISBN 978-3631670101. [CrossRef]

43. Stephens, C.; Porter, J.; Willis, R.; Clark, S.; Nettleton, C. Indigenous people's health-why are they behind everyone, everywhere? Lancet 2005, 366, 10-13. [CrossRef]

44. Stephens, C.; Porter, J.; Nettleton, C.; Willis, R. Disappearing, displaced, and undervalued: A call to action for Indigenous health worldwide. Lancet 2006, 367, 2019-2028. [CrossRef] 
45. Ford, J.D. Indigenous health and climate change. Am. J. Public Health 2012, 102, 1260-1266. [CrossRef] [PubMed]

46. King, M.; Smith, A.; Gracey, M. Indigenous health part 2: The underlying causes of the health gap. Lancet 2009, 374, 76-85. [CrossRef]

47. San Sebastián, M.; Hurtig, A.K. Review of health research on indigenous populations in Latin America, 1995-2004. Salud Publica Mexico 2007, 49, 316-320. [CrossRef]

48. Ford, J.D.; Cameron, L.; Rubis, J.; Maillet, M.; Nakashima, D.; Willox, A.C.; Pearce, T. Including indigenous knowledge and experience in IPCC assessment reports. Nat. Clim. Chang. 2016, 6, 349-353. [CrossRef]

49. Ford, J.D.; Vanderbilt, W.; Berrang-Ford, L. Authorship in IPCC AR5 and its implications for content: Climate change and Indigenous populations in WGII. Clim. Chang. 2011, 113, 201-213. [CrossRef]

50. David-Chavez, D.M.; Gavin, M.C. A global assessment of Indigenous community engagement in climate research. Environ. Res. Lett. 2018, 13, 123005. [CrossRef]

51. Whitehead, P.G.; Wilby, R.L.; Battarbee, R.W.; Kernan, M.; Wade, A.J. A review of the potential impacts of climate change on surface water quality. Hydrol. Sci. J. 2009, 54, 101-123. [CrossRef]

52. Taylor, R.G.; Scanlon, B.; Döll, P.; Rodell, M.; Van Beek, R.; Wada, Y.; Longuevergne, L.; Leblanc, M.; Famiglietti, J.S.; Edmunds, M.; et al. Ground water and climate change. Nat. Clim. Chang. 2013, 3, 322-329. [CrossRef]

53. Bartram, J.; Cairncross, S. Hygiene, sanitation, and water: Forgotten foundations of health. PLoS Med. 2010, 7, 1-9. [CrossRef] [PubMed]

54. Wolf, J.; Prüss-Ustün, A.; Cumming, O.; Bartram, J.; Bonjour, S.; Cairncross, S.; Clasen, T.; Colford, J.M.; Curtis, V.; De France, J.; et al. Systematic review: Assessing the impact of drinking water and sanitation on diarrhoeal disease in low- and middle-income settings: Systematic review and meta-regression. Trop. Med. Int. Heal. 2014, 19, 928-942. [CrossRef] [PubMed]

55. Hofmeijer, I.; Ford, J.D.; Berrang-Ford, L.; Zavaleta, C.; Carcamo, C.; Llanos, E.; Carhuaz, C.; Edge, V.; Lwasa, S.; Namanya, D. Community vulnerability to the health effects of climate change among indigenous populations in the Peruvian Amazon: A case study from Panaillo and Nuevo Progreso. Mitig. Adapt. Strateg. Glob. Chang. 2013, 18, 957-978. [CrossRef]

56. Sherman, M.; Ford, J.; Llanos-Cuentas, A.; Valdivia, M.J.; Bussalleu, A. Vulnerability and adaptive capacity of community food systems in the Peruvian Amazon: A case study from Panaillo. Nat. Hazards 2015, 77, 2049-2079. [CrossRef]

57. Dirección General de Epidemiología. ASIS del Pueblo Shawi 2008; MINSA: Lima, Perú, 2008.

58. Torres-Slimming, P.A.; Wright, C.; Carcamo, C.P.; Garcia, P.J.; IHACC Research Team; Harper, S.L. Achieving the sustainable development goals: A mixed methods study of health-related water, sanitation, and hygiene (WASH) for indigenous shawi in the peruvian amazon. Int. J. Environ. Res. Public Health 2019, 16, 2429. [CrossRef] [PubMed]

59. Odonne, G.; Valadeau, C.; Alban-Castillo, J.; Stien, D.; Sauvain, M.; Bourdy, G. Medical ethnobotany of the Chayahuita of the Paranapura basin (Peruvian Amazon). J. Ethnopharmacol. 2013, 146, 127-153. [CrossRef] [PubMed]

60. Odonne, G.; Bourdy, G.; Castillo, D.; Estevez, Y.; Lancha-Tangoa, A.; Alban-Castillo, J.; Deharo, E.; Rojas, R.; Stien, D.; Sauvain, M. Ta'ta', Huayani: Perception of leishmaniasis and evaluation of medicinal plants used by the Chayahuita in Peru. Part II. J. Ethnopharmacol. 2009, 126, 149-158. [CrossRef]

61. Gutiérrez-Velez, V.H.; Uriarte, M.; Defries, R.; Pinedo-Vasquez, M.; Fernandes, K.; Ceccato, P.; Baethgen, W.; Padoch, C. Land cover change interacts with drought severity to change fire regimes in Western Amazonia. Ecol. Appl. 2014, 24, 1323-1340. [CrossRef]

62. Malhi, Y.; Roberts, J.T.; Betts, R.A.; Killeen, T.J.; Li, W.; Nobre, C.A. Climate change, deforestation, and the fate of the Amazon. Science 2008, 319, 169-173. [CrossRef]

63. Charron, D.F. Ecohealth Research in Practice: Innovative Applications of an Ecosystem Approach to Health; International Development Research Centre and Springer: Ottawa, ON, Canada, 2012; ISBN 9781552505298.

64. Lebel, J. Focus: Health: An Ecosystem Approach; IDRC: Ottawa, ON, Canada, 2003; Volume 15, ISBN 9788578110796.

65. Sherman, M.; Berrang-Ford, L.; Ford, J.; Lardeau, M.P.; Hofmeijer, I.; Cortijo, C.Z. Balancing indigenous principles and institutional research guidelines for informed consent: A case study from the Peruvian Amazon. AJOB Prim. Res. 2012, 3, 53-68. [CrossRef] 
66. Budig, K.; Diez, J.; Conde, P.; Sastre, M.; Hernán, M.; Franco, M. Photovoice and empowerment: Evaluating the transformative potential of a participatory action research project. BMC Public Health 2018, 18, 1-9. [CrossRef] [PubMed]

67. Mahiri, I. Comparing transect walks with experts and local people. PLA Notes 1998, 31, 4-8.

68. Staden, D.; van Rogers, E.; Makaudi, I.; Winkler, J.; White, J.; Kangale, M.; Rudman, N.; Nkosi, S.; Dreyer, T.R.; Coetzer, T. A Transect Walk Undertaken in Itereleng Informal Settlement to Observe Community Vulnerability. Available online: https://sswm.info/node/2013 (accessed on 20 March 2020).

69. Barbour, R.S. Checklists for improving rigour in qualitative research: A case of the tail wagging the dog? BMJ 2001, 322, 1115-1117. [CrossRef] [PubMed]

70. Charmaz, K. Grounded theory method. In Grounded Theory for Qualitative Research: A Practical Guide; Gubrium, J.F., Ed.; Sage Publications: New York, NY, USA, 2008; pp. 397-412. ISBN 13 978-1593853051.

71. Boeije, H. A purposeful approach to the constant comparative method in the analysis of qualitative interviews. Qual. Quant. 2002, 36, 391-409. [CrossRef]

72. Teherani, A.; Martimianakis, T.; Stenfors-Hayes, T.; Wadhwa, A.; Varpio, L. Choosing a qualitative research approach. J. Grad. Med. Educ. 2015, 7, 669-670. [CrossRef] [PubMed]

73. Patton, M.Q. Enhancing the quality and credibility of qualitative analysis. Health Serv. Res. 1999, 34, 1189-1208. [PubMed]

74. Morse, J.M. Approaches to qualitative-quantitative methodological triangulation. Nurs. Res. 2015, 40, 120-123. [CrossRef]

75. Flick, U. Trend report etat de la question qualitative research \pm state of the art. Soc. Sci. Inf. 2002, 41, 5-24. [CrossRef]

76. DeCuir-Gunby, J.T.; Marshall, P.L.; McCulloch, A.W. Developing and using a codebook for the analysis of interview data: An example from a professional development research project. Field Methods 2011, 23, 136-155. [CrossRef]

77. Fereday, J.; Muir-Cochrane, E. Demonstrating rigor using thematic analysis: A hybrid approach of inductive and deductive coding and theme development. Int. J. Qual. Methods 2006, 5, 80-92. [CrossRef]

78. Tong, A.; Sainsbury, P.; Craig, J. Consolidated criterio for reporting qualitative research (COREQ): A 32- item checklist for interviews and focus group. Int. J. Qual. Health Care 2007, 19, 349-357. [CrossRef] [PubMed]

79. O'Brien, B.C.; Harris, I.B.; Beckman, T.J.; Reed, D.A.; Cook, D.A. Standards for reporting qualitative research: A synthesis of recommendations. Acad. Med. 2014, 89, 1245-1251. [CrossRef] [PubMed]

80. Creswell, J.; Miller, D. Determining validity in qualitative inquiry. Theory Pract. 2000, 39, 124-130. [CrossRef]

81. Bull, J.R. Research with Aboriginal peoples: Authentic relationships as a precursor to ethical research. J. Empir. Res. Hum. Res. Ethics 2010, 5, 13-22. [CrossRef]

82. Koster, R.; Baccar, K.; Lemelin, R.H. Moving from research ON, to research with and for indigenous communities: A critical reflection on community-based participatory research. Can. Geogr. 2012, 56, 195-210. [CrossRef]

83. Espinoza, J.C.; Marengo, J.A.; Ronchail, J.; Carpio, J.M.; Flores, L.N.; Guyot, J.L. The extreme 2014 flood in south-western Amazon basin: The role of tropical-subtropical South Atlantic SST gradient. Environ. Res. Lett. 2014, 9, 12. [CrossRef]

84. Cochrane, M.A.; Barber, C.P. Climate change, human land use and future fires in the Amazon. Glob. Chang. Biol. 2009, 15, 601-612. [CrossRef]

85. Laurance, W.F.; Camargo, J.L.C.; Luizão, R.C.C.; Laurance, S.G.; Pimm, S.L.; Bruna, E.M.; Stouffer, P.C.; Williamson, G.B.; Benítez-Malvido, J.; Vasconcelos, H.L.; et al. The fate of Amazonian forest fragments: A 32-year investigation. Biol. Conserv. 2011, 144, 56-67. [CrossRef]

86. Yoon, J.H.; Zeng, N. An Atlantic influence on Amazon rainfall. Clim. Dyn. 2010, 34, 249-264. [CrossRef]

87. Perz, S.G.; Aramburú, C.; Bremner, J. Population, land use and deforestation in the pan Amazon basin: A comparison of Brazil, Bolivia, Colombia, Ecuador, Perú and Venezuela. Environ. Dev. Sustain. 2005, 7, $23-49$. [CrossRef]

88. López-Carr, D.; Burgdorfer, J. Deforestation drivers: Population, migration, and tropical land use. Environment 2013, 55, 3-11. [CrossRef] [PubMed]

89. Piotrowski, M. Nearing the Tipping Point: Drivers of Deforestation in the Amazon Region; Inter-American Dialogue: Washington, WA, USA, 2019.

90. Salati, E.; Vose, P.B. Amazon basin: A system in equilibrium. Science 1984, 225, 129-138. [CrossRef] [PubMed] 
91. Chirif, A.; Álvarez, J.; Timothy, A.; Luisa, B.; Belaunde, E.; Martín, M.; Hugo, B.; Juan, C.; Dammert, L.; Cañas, C.; et al. Peru: Deforestation in Times of Climate Change; IWGIA: Lima, Perú, 2019; ISBN 9788792786951.

92. De Wit, F.C.A. Polycentric Climate Governance and the Amazon Tipping Point. 2018, pp. 19-26. Available online: https://www.scitepress.org/Papers/2018/68202/68202.pdf (accessed on 15 March 2020).

93. Lovejoy, T.E.; Nobre, C. Amazon tipping point. Sci. Adv. 2018, 4, 1-2. [CrossRef] [PubMed]

94. Chu, P.-S.; Yu, Z.-P.; Hastenrath, S. Detecting climate change concurrent with deforestation in the Amazon basin: Which way has it gone? Bull. Am. Meteorol. Soc. 2002, 75, 579-583. [CrossRef]

95. Markandya, A.; Armstrong, B.G.; Hales, S.; Chiabai, A.; Criqui, P.; Mima, S.; Tonne, C.; Wilkinson, P. Public health benefits of strategies to reduce greenhouse-gas emissions: Low-carbon electricity generation. Lancet 2009, 374, 2006-2015. [CrossRef]

96. Mandle, L.; Tallis, H.; Sotomayor, L.; Vogl, A.L. Who loses? Tracking ecosystem service redistribution from road development and mitigation in the Peruvian Amazon. Front. Ecol. Environ. 2015, 13, 309-315. [CrossRef]

97. Reyes-garcía, V.; Paneque-gálvez, J.; Bottazzi, P.; Luz, A.C.; Gueze, M.; Macía, M.J.; Orta-martínez, M.; Pacheco, P. Indigenous land recon fi guration and fragmented institutions: A historical political ecology of Tsimane' lands (Bolivian Amazon). J. Rural Stud. 2014, 34, 282-291. [CrossRef]

98. Avilez, J.L.; Bazalar, J.; Azañedo, D.; Miranda, J.J. Peru, climate change and non-communicable diseases: ¿Where are we and where are we headed? Rev. Peru. Med. Exp. Salud Publica 2016, 33, 143-148. [CrossRef]

(C) 2020 by the authors. Licensee MDPI, Basel, Switzerland. This article is an open access article distributed under the terms and conditions of the Creative Commons Attribution (CC BY) license (http://creativecommons.org/licenses/by/4.0/). 